\title{
Morphological Analysis and Morphometry of the Foramen Magnum: An Anatomical Investigation
}

\author{
Foramen Magnum Morfolojik Analizi ve Morfometrisi: \\ Anatomik Bir Inceleme
}

P. CHETHAN ${ }^{1}$, K.G. PRAKASH ${ }^{2}$, B.V. MURLIMANJU ${ }^{1}$, K.U. PRASHANTH ${ }^{1}$, Latha V. PRABHU ${ }^{1}$, Vasudha V. SARALAYA $^{1}$, Ashwin KRISHNAMURTHY', M.S. SOMESH ${ }^{3}$, C. Ganesh KUMAR ${ }^{1}$

${ }_{1}^{1}$ Manipal University, Centre for Basic Sciences, Kasturba Medical College, Department of Anatomy, Mangalore, India

${ }^{2}$ Azeezia Institute of Medical Sciences, Department of Anatomy, Meeyyannoor, Kollam, Kerala, India

${ }^{3}$ Sri Sreenivas Institute of Medical Sciences and Research, Department of Anatomy, Mukka, Mangalore, India

Correspondence address: B.V.MURLIMANJU / E-mail: flutesnowmm@gmail.com

\begin{abstract}
AIM: The objectives were to study the morphology of the foramen magnum in dry skulls and to evaluate its antero-posterior diameter, transverse diameter and the foramen magnum index.

MATERIAL and METHODS: The foramen magna of 53 dry human cadaver skulls that were obtained from the neuroanatomy laboratory were examined. Different shapes of the foramen magnum were macroscopically noted and classified. The antero-posterior and transverse diameters were measured and the average foraminal index was calculated.

RESULTS: The foramen magnum shapes were determined as a round shape in $22.6 \%$ of cases, egg shape in $18.9 \%$, tetragonal in $18.9 \%$, oval in $15.1 \%$, irregular in $15.1 \%$, hexagonal in $5.6 \%$ and pentagonal in $3.8 \%$ of the cases. In $20.7 \%$ of skulls, the occipital condyle was observed to protrude into the foramen. The mean antero-posterior and transverse diameter of the foramen magnum was determined as $31 \pm 2.4 \mathrm{~mm}$ and $25.2 \pm 2.4 \mathrm{~mm}$ respectively. The average foramen magnum index was $1.2 \pm 0.1$.

CONCLUSION: The present study has determined the various shapes of foramen magnum and its morphometry. The data obtained may be of useful to the neurosurgeon in analyzing the morphological anatomy of craniovertebral junction. The findings are also enlightening for the anthropologists, morphologists and clinical anatomists.
\end{abstract}

KEYWORDS: Foramen magnum, Morphology, Morphometry, Shape, Skull

öz

AMAÇ: Foramen magnumun kuru kafataslarında morfolojisini incelemek ve anterioposterior çap, transvers çap ve foramen magnum indeksini değerlendirmek.

YÖNTEM ve GEREÇLER: Nöroanatomi laboratuvarından elde edilen 53 kuru insan kadavra kafatasının foramen magnumları incelendi. Farklı foramen magnum şekilleri makroskopik olarak kaydedildi ve sınıflandırıldı. Antero-posterior ve transvers çaplar ölçüldü ve ortalama foramen indeksi hesaplandı.

BULGULAR: Foramen magnum şekilleri vakaların \%22,6'sında yuvarlak, \%18,9'unda yumurta şekilli, \%18,9'unda tetragonal, \%15,1'inde oval, $\% 15,1$ 'inde düzensiz, \%5,6'sında ekstragonal ve \%3,8'inde pentagonaldi. Kafataslarının \%20,7'sinde oksipital kondilin foramene doğru çıkıntı yaptığı gözlendi. Foramen magnumun ortalama anteroposterior ve transvers çapı sırasıyla $31 \pm 2,4 \mathrm{~mm}$ ve $25,2 \pm 2,4 \mathrm{~mm}$ olarak belirlendi. Ortalama foramen magnum indeksi 1,2 $\pm 0,1$ bulundu.

SONUÇ: Mevcut çalışma foramen magnumun çeşitli şekilleri ve morfometrisini belirlemiştir. Elde edilen veriler nörocerraha kraniyovertebral bileşke morfolojik anatomisini analiz etmek açısından faydalı olabilir. Bulgular ayrıca antropologlar, morfologlar ve klinik anatomistler için faydalıdır.

ANAHTAR SÖZCÜKLER: Foramen magnum, Morfoloji, Morfometri, Şekil, Kafatası

\section{INTRODUCTION}

The foramen magnum (FM) is an important landmark of the base of skull and is of particular interest to many fields of medicine (4). Variations of the shape of FM have got diagnostic, clinical and radiological importance (6). Also there exists some correlation between the shape of FM and ancestry of an individual. The dimensions of FM have clinical importance because the vital structures that pass through it may suffer compression as in cases of FM achondroplasia (5) and FM brain herniation $(9,10)$. In neurosurgical practice, the transcondylar approach is commonly used to access the lesions which are ventral to the brainstem and cervicomedullary junction. It was reported that understanding the bony anatomy of the condylar region is important for this approach (7). 
Consequently, assessment of the FM dimensions in relation to the hindbrain tissue gives clue for the initiation and propagation of Chiari I symptomatology (3). Despite its particular clinical importance, there are only a very few anatomical reports are available in the literature. The goal of this research work was to document and analyze the foramen magnum shapes and to determine the average dimensions of the FM in dry cadaver skulls.

\section{MATERIAL and METHODS}

Human adult cadaver dry skulls which were available in the neuroanatomy laboratory of our institution were examined in the present study. The study included 53 dry skulls of Indian population. The exact age and sexes of the skulls were not determined. The different shapes of FM were macroscopically noted and classified as oval, round, egg, tetragonal, pentagonal, hexagonal and irregular shapes. The shapes were determined after the discussion with team of three members in order to avoid observational bias. The antero-posterior and transverse diameters of the FM were measured using vernier calipers of $0.2 \mathrm{~mm}$ accuracy. The antero-posterior diameter was measured from the end of anterior border (basion) to the end of posterior border (opisthio). The transverse diameter was measured from the point of maximum concavity on the right margin to the maximum concavity on the left margin. The FM index was calculated by dividing the antero-posterior diameter by the transverse diameter. The data were analyzed and presented as mean \pm SD.

\section{RESULTS}

The various shapes of FM which were observed in the present study are shown in Figure 1. The FM was observed to have round shape in $22.6 \%$, egg shape in $18.9 \%$, tetragonal in $18.9 \%$, oval in $15.1 \%$, irregular in $15.1 \%$, hexagonal in $5.6 \%$ and pentagonal in $3.8 \%$ of the cases. The frequencies of different shapes of FM are represented in Table I. In 11 (20.7\%) of the skulls, the occipital condyle was observed to protrude into the FM (Figure 2). The mean antero-posterior and transverse diameter of the FM was recorded as $31 \pm 2.4 \mathrm{~mm}$ and $25.2 \pm$ $2.4 \mathrm{~mm}$ respectively. The average FM index was calculated as $1.2 \pm 0.1$.

\section{DISCUSSION}

It was reported that some of the osteological features in the skull like FM have undergone evolutionary changes $(8,13)$. During the early fetal growth, the development of skull base begins as a cartilaginous mass with multiple centers of ossification and the FM alone is one such center (13). It was described that the FM is morphologically variable. The irregular shape of FM is accentuated by the developmental anomalies of the bone and soft tissues at the cranio-vertebral junction (3). The FM is usually described as oval in shape (6).

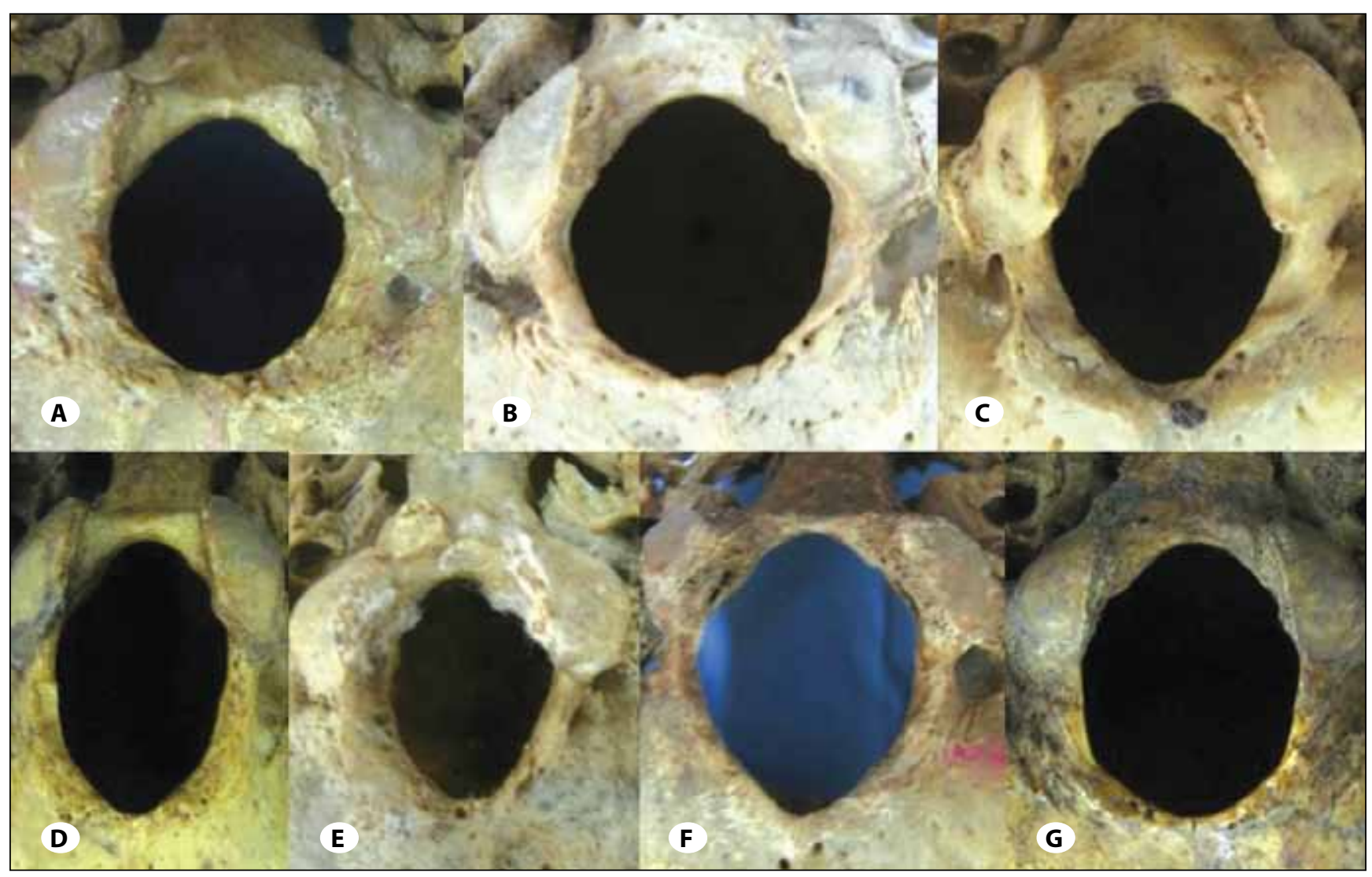

Figure 1: Showing the morphological variants of the shapes of foramen magnum (A- round shape; B- egg shape; C-tetragonal; D- oval; E- irregular; F- hexagonal and G- pentagonal shape). 
Zaidi and Dayal (19), observed the oval shape FM in $64 \%$ of their specimens. However, Sindel et al. (14) observed the oval foramen in only $18.9 \%$ of the skulls and in $81.1 \%$ of the cases the shapes of the foramina were of different shapes. According to Murshed et al. (6), the FM was found to be oval in $8.1 \%$, egg-shaped in $6.3 \%$, round in $21.8 \%$, tetragonal in $12.7 \%$, pentagonal in $13.6 \%$, hexagonal in $17.2 \%$, irregular (A) in $10.9 \%$ and irregular (B) in $9.1 \%$ of the cases. Their study involved the examination of computer tomogram films in the healthy individuals. Depending upon the peculiar shape among the irregular types, they classified the irregular type into irregular (A) and irregular (B). In the present study with the dry skull photographs, we couldn't able to classify the irregular ones further. So we considered all the foramina which were other than the classified shapes as irregular ones. Zaidi and Dayal (19) reported the hexagonal shape in $24.5 \%$,

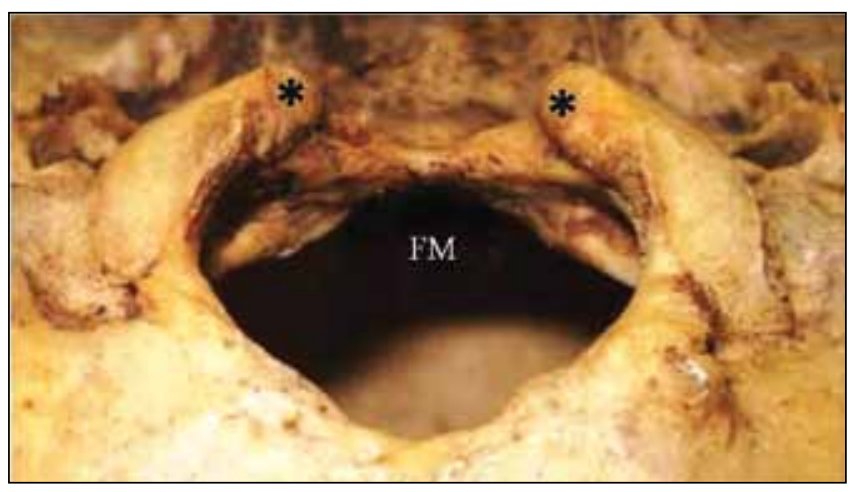

Figure 2: Photograph of the skull showing the occipital condyles $\left({ }^{*}\right)$ encroaching the foramen magnum (FM).

Table I: Showing the Frequency of Different Shapes of Foramen Magnum $(n=53)$

\begin{tabular}{|l|c|}
\hline morphological variants of FM & frequency and number \\
\hline round shape & $22.6 \%(12)$ \\
\hline egg shape & $18.9 \%(10)$ \\
\hline tetragonal shape & $18.9 \%(+10)$ \\
\hline oval shape & $15.1 \%(8)$ \\
\hline irregular shape & $15.1 \%(8)$ \\
\hline hexagonal shape & $5.6 \%(3)$ \\
\hline pentagonal shape & $3.8 \%(2)$
\end{tabular}

pentagonal in $7.5 \%$, irregular in $3.5 \%$ and round in $0.5 \%$ of the skulls. In contrast, Sindel et al. (14) reported that the FM was hexagonal in 5.3\%, pentagonal in $4.2 \%$, irregular in $6.3 \%$, round in $15.8 \%$ and tetragonal in $49.4 \%$ of the subjects.

In the present study, the FM was observed to have round shape in 12 cases (22.6\%), egg shape in 10 (18.9\%), tetragonal in 10 (18.9\%), oval in $8(15.1 \%)$, irregular in $8(15.1 \%)$, hexagonal in $3(5.6 \%)$ and pentagonal in $2(3.8 \%)$ of the cases. The difference in shapes of the FM from various reports indicates racial variability among the morphology. The present study agrees with Murshed et al. (6) as in both these studies the round shape was the most common type. In $20.7 \%$ of the cases, the occipital condyles were protruded into the FM. The same frequency was observed by Muthukumar et al. (7), 20\% of their skulls showed the occipital condyle protruding into the FM. This type of morphology can lead to compression of structures passing through the FM. Murshed et al. (6) opined that the focus of further studies includes, the relationships between the variant shapes and vital structures passing through it. They concluded that variation in the FM shape should be taken into consideration during the clinical and radiological diagnostic procedures and the surgical approach.

It is interesting to study the morphometry of the FM, from a descriptive and topographical point of view (6). The anatomic diameters have been reported to be about $35 \mathrm{~mm}$ for the sagittal diameter and $30 \mathrm{~mm}$ for the transverse diameter $(11,15)$. The radiologic values obtained by Wackenheim (17) were $35 \mathrm{~mm}$ for the sagittal diameter and $30 \mathrm{~mm}$ for the transverse diameter, whereas Zaragoza (20) obtained mean values of $38 \mathrm{~mm}$ for the sagittal diameter and $28 \mathrm{~mm}$ for transverse diameter. Similar values were obtained by Testut and Latarjet (15), in their study, the average antero posterior length of the FM was $33.3 \mathrm{~mm}$ and the width was $27.9 \mathrm{~mm}$. They stated that longer FM antero-posterior dimensions permitted greater contralateral surgical exposure for condylar resection. The data obtained from the present study was compared with few more reports from other authors and the same has been represented in Table II. After the comparison, we observed that, the data from the present study are slightly lesser than the previous reports. But our findings are almost similar to that of Tubbs et al (16). In the present study, the average FM index was calculated as $1.2 \pm 0.1$. Testut and Latarjet (15) opined that wide, sagittally inclined and medially protruberant occipital condyles along with a FM index more

Table II: Showing the Comparison of Morphometric Data of FM with the Previous Reports

\begin{tabular}{|c|c|c|}
\hline authors & sagittal diameter & transverse diameter \\
\hline Schmeltzer et al. (12), 1971 & $35 \mathrm{~mm}$ & $30 \mathrm{~mm}$ \\
\hline Catalina-Herrera (2), 1987 & $35.2 \mathrm{~mm}$ & $30.3 \mathrm{~mm}$ \\
\hline Wanebo and Chicoine (18), 2001 & $36 \pm 2 \mathrm{~mm}$ & $32 \pm 2 \mathrm{~mm}$ \\
\hline Murshed et al (6), 2003 & $35.9 \pm 3.3 \mathrm{~mm}$ & $30.4 \pm 2.6 \mathrm{~mm}$ \\
\hline Tubbs et al (16), 2010 & $31 \mathrm{~mm}$ & $27 \mathrm{~mm}$ \\
\hline Present study, 2011 & $31 \pm 2.4 \mathrm{~mm}$ & $25.2 \pm 2.4 \mathrm{~mm}$ \\
\hline
\end{tabular}


than 1.2 will require much more extensive bony resection while surgeries.

In transcondylar approach, the anatomical landmarks of the FM should be well known in order to make a safe occipital condyle resection (1). The present study elucidates the morphometric data and the variations in the morphology of the FM with emphasis on their clinical implications. These morphological characteristics have medicolegal importance and helps in the identification of unknown individuals. Though the present study has a limitation as the exact age and sexes of skull were not determined, this study may provide an important reference and the measurements may be used as a data for the description of normal morphological variants of FM. Since the anatomy of the FM is of interest to many fields of medicine due to increased application of CT and MRI scans, this investigation was undertaken. We believe that the data obtained from the present study will be of useful to the neurosurgeons and is also certainly enlightening to the anthropologists, morphologists and clinical anatomists.

\section{REFERENCES}

1. Barut N, Kale A, Turan Suslu H, Ozturk A, Bozbuga M, Sahinoglu K: Evaluation of the bony landmarks in transcondylar approach. Br J Neurosurg 23:276-281, 2009

2. Catalina-Herrera CJ: Study of the anatomic metric values of the foramen magnum and its relation to sex. Acta Anat 130:344-347, 1987

3. Furtado SV, Thakre DJ, Venkatesh PK, Reddy K, Hegde AS: Morphometric analysis of foramen magnum dimensions and intracranial volume in pediatric chiari I malformation. Acta Neurochir (Wien) 152:221-227, 2010

4. Gruber $P$, Henneberg M, Boni T, Ruhli FJ: Variability of human foramen magnum size. Anat Rec 292:1713-1719, 2009

5. Hecht JT, Horton WA, Reid CS, Pyeritz RE, Chakraborty R: Growth of the foramen magnum in achondroplasia. Am J Med Genet 32:528-535, 1989

6. Murshed KA, Cicekcibasi AE, Tuncer I: Morphometric evaluation of the foramen magnum and variations in its shape: A study on computerized tomographic images of normal adults. Turk J Med Sci 33:301-306, 2003
7. Muthukumar N, Swaminathan R, Venkatesh G, Bhanumathy $\mathrm{SP}: \mathrm{A}$ morphometric analysis of the foramen magnum region as it relates to the transcondylar approach. Acta Neurochir (Wien) 147:889-895, 2005

8. Nevell L, Wood B: Cranial base evolution within the hominin clade. J Anat 212:455-468, 2008

9. Reich JB, Sierra J, Camp W, Zanzonico P, Deck MD, Plum F: Magnetic resonance imaging measurements and clinical changes accompanying transtentorial and foramen magnum brain herniation. Ann Neurol 33:159-170, 1993

10. Ropper AH: MRI demonstration of the major features of herniation. J Neurol Neurosurg Psychiatry 56:932-935, 1993

11. Rouviere $\mathrm{H}$ : Anatomia humana descriptiva y topografica. Madrid: Bailly Bailliere, 1956

12. Schmeltzer A, Babin E, Wenger JJ: Measurement of the foramen magnum in children and adults. Neuroradiology 2(3):162-163, 1971

13. Scott JH: The cranial base. Am J Phys Anthropol 16:319-348, 1958

14. Sindel M, Ozkan O, Ucar $Y$, et al: Foramen magnum'un anatomik varyasyonları. Akd U Tip Fak Dergisi 6:97-102, 1989

15. Testut $L$, Latarjet A:Tratado de Anatomia humana. Barcelona: Salvat, 1977

16. Tubbs RS, Griessenauer CJ, Loukas M, Shoja MM, CohenGadol AA: Morphometric analysis of the foramen magnum: An anatomic study. Neurosurgery 66:385-388, 2010

17. Wackenheim A: Roentgen diagnosis of the craniovertebral region. NewYork: Springer, 1974

18. Wanebo JE, Chicoine MR: Quantitative analysis of the transcondylar approach to the foramen magnum. Neurosurgery 49:934-941, 2001

19. Zaidi SH, Dayal SS: Variations in the shape of foramen magnum in Indian skulls. Anat Anz Jena 167:338-340, 1988

20. Zaragoza E: Malformaciones de la charnela occipito-cervical y sus correlaciones clinicas. Ministerio del Trabajo. IN de Previsi.n: Madrid, 1974 